\title{
C-reactive protein is an independent predictor for carotid artery intima-media thickness progression in asymptomatic younger adults (from the Bogalusa Heart Study)
}

Ahmet Toprak ${ }^{1}$, Ramprasad Kandavar², Demet Toprak ${ }^{3}$, Wei Chen ${ }^{4}$, Sathanur Srinivasan ${ }^{4}$, Ji Hua Xu ${ }^{4}$, Asif Anwar and Gerald S Berenson ${ }^{4^{*}}$

\begin{abstract}
Background: Conflicting information exists regarding the association between hsCRP and the progression of early stages of atherosclerosis. The purpose of the study was to investigate the association of high sensitiviy c-reactive protein (hsCRP) along with major cardiovascular (CV) risk factors on early carotid atherosclerosis progression in a large, population-based cohort study.

Methods: The study cohort included 839 young adults (aged 24 to 43 years, 70\% white, 42\% men) enrolled in Bogalusa Heart Study, who in 2001-2002 attended baseline examination with measurements of CV risk factors. Progression of carotid artery intima-media thickness (IMT) was assessed during a mean follow-up of 2.4 years.

Results: Carotid artery IMT progression rates were as follows: composite carotid artery $=9.2 \pm 52 \mu \mathrm{m} / \mathrm{y}$, common carotid artery $=0.0 \pm 51 \mu \mathrm{m} / \mathrm{y}$, carotid bulb $=8.8 \pm 103 \mu \mathrm{m} / \mathrm{y}$, and internal carotid artery $=18.9 \pm 81 \mu \mathrm{m} / \mathrm{y}$.

Elevated baseline hsCRP, reflecting an inflammatory state, showed independent association with composite carotid artery IMT progression. Increased age, systolic blood pressure, fasting glucose, LDL cholesterol, and current smoking were other risk associates of carotid artery IMT progression in young adults, indicating an underlying burden on the CV system by multiple risk factors.

Conclusion: In this population-based study, we observed independent categorical association of increased hsCRP with carotid artery IMT progression in young adults. This study underlines the importance of assesssing hsCRP levels along with smoking and traditional CV risk factor profiles in asymptomatic young adults.
\end{abstract}

Keywords: Carotid artery intima-media thickness progression, cardiovascular risk, c-reactive protein, epidemiology, young adults

\section{Background}

Carotid artery intima-media thickness (IMT), as assessed noninvasively by ultrasonography, is a useful measure of preclinical atherosclerosis and has been found to predict future risk for myocardial infarction, stroke, and death from coronary heart disease. A change in carotid artery IMT over time has been validated as a vascular marker of the progression of atherosclerosis [1]. Such longitudinal changes in carotid artery IMT provides further

\footnotetext{
* Correspondence: berenson@tulane.edu

${ }^{4}$ Tulane Center for Cardiovascular Health, New Orleans, LA, USA

Full list of author information is available at the end of the article
}

pathophysiologic insights into atherogenesis. Childhood risk factors were associated with carotid artery IMT in young adulthood in the Bogalusa Heart Study [2], and an increasing risk factor burden was associated with increased aortic and coronary atherosclerosis found at autopsy in young adults [3]. Although traditional CV risk factors for atherosclerosis are well known $[4,5]$, increasing evidence implicates inflammation in the pathogenesis of atherosclerosis and CV disease. Independent association between elevated high sensitivity c-reactive protein (hsCRP) and carotid artery IMT progression has revealed contradictory results [6-12]. High

\section{C) Biomed Central}


sensitivity CRP may reflect an exaggerated inflammatory response associated with traditional $\mathrm{CV}$ risk factors or reflect the causal role of inflammation in the initiation and/or progression of atherosclerosis, further observations are needed.

As part of the Bogalusa Heart Study, a biracial (blackwhite) community based epidemiological study of the early natural history of cardiovascular (CV) disease, the present study examines the relationships of baseline traditional CV risk factors and hsCRP to carotid artery IMT progression in asymptomatic younger adults by race and sex.

\section{Methods}

\subsection{Study cohort and design}

The Bogalusa Heart Study is a long-term epidemiologic study of the early natural history of arteriosclerosis in children and young adults from a semirural, biethnic (65\% white, $35 \%$ black) community in Bogalusa, Louisiana [13]. This report includes a cohort of 839 subjects $(70 \%$ white, $42 \%$ men) who were examined in both the 2001-2002 survey (mean age, $36.6 \pm 4.3$ years; range, 24 to 43 years) and the 2003-2005 survey (mean age, $39.0 \pm 4.3$ years; range, 26 to 46 years) for CV risk factors and carotid artery IMT. All subjects in this study gave informed consent for examinations. Study protocols were approved by the Institutional Review Board of the Tulane University Health Sciences Center.

\subsection{General examinations}

Standardized protocols were used by trained examiners [14]. Height and weight were measured in triplicate, and the mean values were used to calculate body mass index $(\mathrm{BMI}=$ weight in kilograms divided by the square of the height in meters) as a measure of overall obesity. Mean waist circumference divided by height was used as an indicator of visceral fatness. Right arm blood pressure was measured in triplicate with mercury sphygmomanometers by 2 trained observers while subjects were seated and relaxed. The first and fifth Korotkoff phases were used to determine systolic and diastolic blood pressure, respectively; means of 6 replicate readings were used.

\subsection{Laboratory analysis}

Subjects were instructed to fast for 12 hours before screening, and compliance was determined by interview on the morning of examination. Plasma glucose was measured by a glucose oxidase method as part of the multiple chemistry profile (SMA20) in the multichannel Olympus Au-5000 Analyzer (Olympus, Lake Success, NY). A radioimmunoassay kit was used to measure plasma insulin (Phadebas insulin kit, Pharmacia Diagnostics, Piscataway, NJ). Serum cholesterol and triglycerides were determined enzymatically on the Hitachi 902 Automatic Analyzer
(Roche Diagnostics, Indianapolis, Ind.). Serum lipoprotein cholesterols were analyzed by a combination of heparincalcium precipitation and agar-agarose gel electrophoresis procedures. Plasma high sensitivity c-reactive protein (CRP) was measured by latex particle-enhanced immunoturbidimetric assay on the Hitachi 902 Automatic Analyzer. Urinary albumin excretion was assessed on a morning spot urine sample using an enzyme-linked immunosorbent assay kit (Exocell, Philadelphia, Pa.). The laboratory is being monitored by a surveillance program of the Centers for Disease Control and Prevention, Atlanta, Ga. Intraclass correlation coefficients, a measure of reproducibility of the entire process from blood collection to data processing, between the blind duplicate values $(n=103)$ were 0.98 for total cholesterol, 0.99 for high-density lipoprotein (HDL) cholesterol, and 0.98 for glucose.

\subsection{Carotid ultrasonography}

Trained sonographers performed ultrasound examinations using the Toshiba Ultrasound instruments (Toshiba SonoLayer SSH 160A and Toshiba Power Vision SSH380, Toshiba America Medical Systems, Tustin, Ca.) with 7.5- $\mathrm{MHz}$ linear array transducers. B-mode images were recorded at the common catotid, carotid bulb (bifurcation), and internal carotid arteries bilaterally according to previously developed protocols for the Atherosclerosis Risk in Communities study [15]. Images were recorded on S-VHS $1 / 2$ " tapes and read centrally by certified readers at the Division of Vascular Ultrasound Research, Wake Forest University School of Medicine, using a semiautomatic ultrasound image processing program developed by the California Institute of Technology Jet Propulsion Laboratory (Pasedena, Ca.) according to strict protocols [16]. Previous readings from 2001-2002 were accepted as baseline values. The mean of the maximum carotid IMT readings of 3 right and 3 left far walls for common, bulb, and internal segments was used. Images were read at the same cardiac cycle, which was end diastole. If bilateral images were not available, the value of one side was used as the mean. The trained sonographers were blinded to risk factor data. Reproducibility (mean difference \pm SD) of composite carotid artery IMT (average of the segmental maximum carotid IMT measurements) in 141 subjects (69 from 2001-2002 survey and 72 from 2003-2005 survey) was $15.1 \pm 84.4 \mu \mathrm{m}$ for mean maximum thickness corresponding with a $99 \%$ confidence interval (CI) of -3.4 to $33.7 \mu \mathrm{m}$.

\subsection{Statistical methods}

All data analyses were performed using SPSS software (SPSS Inc., Chicago, Il.). Insulin, triglycerides and urinary albumin-creatinine ratio were log-transformed to improve the normality of distribution; however, their mean values in original scales are presented for description. Differences 
in mean values of study variables between race-sex groups were tested by analysis of covariance models. Cardiovascular risk factors and carotid artery IMT at each survey were described by mean \pm SD values and contrasted by paired t-test or McNemar test. The impact of the correlates on composite carotid artery IMT progression was examined by stepwise linear regression model in the total sample. Composite carotid artery IMT progression was adjusted for the baseline (2001-2002 survey) composite carotid artery IMT and the risk model included baseline age, gender, race, systolic and diastolic blood pressures, waistheight ratio, fasting glucose, serum low-density lipoprotein (LDL) cholesterol, HDL cholesterol, fasting triglycerides, high-sensitivity c-reactive protein $\geq 2 \mathrm{mg} / \mathrm{l}$ and smoking status with a p-value criteria of $<0.05$.

\section{Results}

Table 1 shows the baseline and follow-up CV risk factors at each survey by race and sex. Significant race differences were noted in both sexes for systolic and diastolic blood pressures (whites < blacks), and the prevalence of high sensitivity c-reactive protein $\geq 2 \mathrm{mg} / \mathrm{l}$ (whites < blacks); however, the race differences in age (whites > blacks), BMI (whites < blacks), waist-height ratio (whites $<$ blacks), glucose (whites < blacks), insulin (whites < blacks), and triglycerides (whites $>$ blacks) were significant only in females. The race difference in HDL cholesterol (whites < blacks), total cholesterol-HDL cholesterol ratio (whites $>$ blacks), and the prevalence of current smoking (whites < blacks) were significant only in males. Compared with women, men showed higher values of systolic and diastolic blood pressures, serum triglycerides, and total cholesterol-HDL cholesterol ratio; men had lower BMI and higher prevalence of current smoking in blacks only; however, men had lower HDL cholesterol and the prevalence of high sensitivity c-reactive protein $\geq$ $2 \mathrm{mg} / \mathrm{l}$ in whites only. Waist-height ratio and serum insulin were higher white men $>$ white women and black women $>$ black men. Significant increases in age (all race-sex groups), BMI (whites), waist-height ratio (white women), serum glucose (all except black men), LDL cholesterol (white men), and HDL cholesterol (white women); however significant decreses in diastolic blood pressure and total cholesterol-HDL cholesterol ratio (black men) were observed between 2 surveys. Significant sex difference for BMI and waist-height ratio were no longer evident in the follow-up survey, while glucose showed a significant sex difference (white men $>$ white women).

Carotid IMT measurements and progression rates were presented in Tables 2 and 3, respectively. At the baseline survey, significant race differences were noted in both sexes for common carotid artery IMT (whites < blacks); however, the race differences in composite carotid artery
IMT (whites < blacks), and carotid bulb IMT (whites < blacks) were significant only in females. Compared with women, men showed higher values for composite, common, bulb, and internal carotid artery IMT. Significant race differences for composite carotid artery and carotid bulb IMT were no longer evident in the second survey. Composite carotid artery (all except black men), carotid bulb (white women), and internal carotid artery (all except black men) IMT showed significant progression between the two surveys (Table 2). Carotid IMT progression rates were as follows (Table 3): composite carotid artery $=9.2 \pm 52 \mu \mathrm{m} / \mathrm{y}$, common carotid artery $=0.0 \pm$ $51 \mu \mathrm{m} / \mathrm{y}$, carotid bulb $=8.8 \pm 103 \mu \mathrm{m} / \mathrm{y}$, and internal carotid artery $=18.9 \pm 81 \mu \mathrm{m} / \mathrm{y}$ (Figure 1). Carotid artery IMT progression rates did not differ significantly among race-sex groups.

Baseline CV risk correlates of the composite carotid artery IMT progression are presented in Table 4. Composite carotid artery IMT progression was adjusted for the baseline (2001-2002 survey) composite carotid artery IMT, which showed a significant association with an unstandardized difference of -0.296 ( $[95 \%$ CI between -0.353 and -0.240], $\mathrm{p}<0.001$ ). Based on the magnitude of adjusted difference in the total sample, increase in baseline age, systolic blood pressure, fasting glucose, prevalence of high sensitivity c-reactive protein $\geq 2 \mathrm{mg} / \mathrm{l}$, LDL cholesterol, and prevalence of current smoking were, in that order, associated with the composite carotid artery IMT progression.

\section{Discussion}

In this large community population, we identified the association of baseline traditional CV risks and hsCRP to carotid artery IMT progression in young adults (24- to 43year old) over a 2.4-year period. The major finding was that in addition to increase in baseline age, systolic blood pressure, glucose, LDL cholesterol and the prevalence of current smoking, increase in the prevalence of baseline hsCRP $\geq 2 \mathrm{mg} / \mathrm{l}$ were associated with the composite carotid artery IMT progression independent of other traditional CV risks. An earlier report from the Bogalusa Heart Study demonstrated that smoking was the most consistent predictor of carotid artery IMT progression in 336 young men and women, who were screened in both 1995-1996 and 2000-2001 surveys, during an average follow-up of 5.8 years [4]. The prior reported composite and common carotid artery IMT progression rates of $17 \mu \mathrm{m} / \mathrm{y}$ and $16 \mu \mathrm{m} / \mathrm{y}$ were much higher than the current composite and common of $9.2 \mu \mathrm{m} / \mathrm{y}$ and $0.0 \mu \mathrm{m} / \mathrm{y}$ in 839 young men and women. The rate of progression over a 2.4-year period is relatively short and may be responsible for the inability to detect a significant progression of IMT in the common carotid artery segment. Nevertheless, current report expands the findings of this earlier article, in which the 
Table 1 Baseline and follow-up cardiovascular risk characteristics of study cohort by race and sex

\begin{tabular}{|c|c|c|c|c|c|c|}
\hline \multirow[b]{2}{*}{ Baseline survey (2001-2002) } & \multicolumn{2}{|c|}{ White } & \multicolumn{2}{|c|}{ Black } & \multicolumn{2}{|c|}{$P$ value* } \\
\hline & $\begin{array}{c}\text { Men } \\
(\mathrm{n}=266)\end{array}$ & $\begin{array}{c}\text { Women } \\
(n=324)\end{array}$ & $\begin{array}{c}\text { Men } \\
(\mathrm{n}=\mathbf{8 5}) \\
\end{array}$ & $\begin{array}{c}\text { Women } \\
(n=164)\end{array}$ & Race & Sex \\
\hline Age, years & $37.0 \pm 4.2^{9}$ & $36.7 \pm 4.2^{9}$ & $36.9 \pm 3.8$ & $35.5 \pm 4.7^{\mathbb{9}}$ & $<0.05^{f}$ & NS \\
\hline $\mathrm{BMI}, \mathrm{kg} / \mathrm{m}^{2}$ & $29.2 \pm 5.8^{4}$ & $28.3 \pm 7.2^{\pi}$ & $29.8 \pm 7.1$ & $32.9 \pm 9.1$ & $<0.001^{f}$ & $<0.01^{\mathrm{b}}$ \\
\hline Waist/height & $0.56 \pm 0.08$ & $0.53 \pm 0.1^{\Re}$ & $0.55 \pm 0.09$ & $0.59 \pm 0.11$ & $<0.001^{f}$ & $<0.05$ \\
\hline Systolic blood pressure, $\mathrm{mm} \mathrm{Hg}$ & $118 \pm 11$ & $111 \pm 11$ & $129 \pm 17$ & $120 \pm 16$ & $<0.001$ & $<0.001$ \\
\hline Diastolic blood pressure, $\mathrm{mm} \mathrm{Hg}$ & $80 \pm 8$ & $75 \pm 8$ & $88 \pm 13^{\ddagger}$ & $80 \pm 11$ & $<0.001$ & $<0.001$ \\
\hline Fasting glucose, mg/dl & $88 \pm 24^{\pi}$ & $84 \pm 20^{\S}$ & $91 \pm 33$ & $91 \pm 35^{\S}$ & $<0.05^{\mathrm{f}}$ & NS \\
\hline Fasting insulin, $\mu \mathrm{U} / \mathrm{ml}^{\dagger}$ & $12.8 \pm 8.9$ & $11.3 \pm 8.3$ & $12.2 \pm 9.0$ & $15.3 \pm 12.1$ & $<0.001^{f}$ & $<0.05$ \\
\hline LDL cholesterol, mg/dl & $130 \pm 34^{\ddagger}$ & $124 \pm 33$ & $124 \pm 45$ & $118 \pm 33$ & NS & NS \\
\hline Fasting triglycerides, $\mathrm{mg} / \mathrm{dl}^{+}$ & $165 \pm 129$ & $118 \pm 69$ & $147 \pm 126$ & $88 \pm 37$ & $<0.001^{f}$ & $<0.001$ \\
\hline HDL cholesterol, mg/dl & $41 \pm 12$ & $51 \pm 13^{\ddagger}$ & $50 \pm 13$ & $51 \pm 13$ & $<0.001^{\mathrm{m}}$ & $<0.001^{w}$ \\
\hline Total cholesterol/HDL cholesterol & $5.0 \pm 1.4$ & $4.0 \pm 1.1$ & $4.3 \pm 1.6^{\ddagger}$ & $3.8 \pm 1.2$ & $<0.001^{\mathrm{m}}$ & $<0.05$ \\
\hline High-sensitivity C-reactive protein $\geq 2 \mathrm{mg} / \mathrm{l}$ & $32.6 \%$ & $47.3 \%$ & $47.1 \%$ & $58.1 \%$ & $<0.05$ & $<0.001^{w}$ \\
\hline Current smoker & $34.7 \%$ & $27.2 \%$ & $53.6 \%$ & $32.2 \%$ & $<0.01^{\mathrm{m}}$ & $<0.01^{\mathrm{b}}$ \\
\hline \multicolumn{7}{|l|}{ Follow-up survey (2003-2005) } \\
\hline Age, years & $39.3 \pm 4.2^{9}$ & $39.1 \pm 4.2^{n}$ & $39.2 \pm 3.8^{\pi}$ & $37.9 \pm 4.7^{9}$ & $<0.05^{f}$ & NS \\
\hline $\mathrm{BMI}, \mathrm{kg} / \mathrm{m}^{2}$ & $29.8 \pm 6.2^{n}$ & $28.8 \pm 7.6^{\pi}$ & $30.0 \pm 7.5$ & $33.6 \pm 9.3$ & $<0.01^{f}$ & NS \\
\hline Waist/height & $0.56 \pm 0.08$ & $0.54 \pm 0.1^{\Re}$ & $0.55 \pm 0.1$ & $0.59 \pm 0.11$ & $<0.01^{f}$ & NS \\
\hline Systolic blood pressure, mm Hg & $118 \pm 12$ & $111 \pm 12$ & $128 \pm 17$ & $121 \pm 17$ & $<0.01$ & $<0.01^{\mathrm{w}}$ \\
\hline Diastolic blood pressure, $\mathrm{mm} \mathrm{Hg}$ & $80 \pm 9$ & $75 \pm 8$ & $86 \pm 14^{\ddagger}$ & $81 \pm 12$ & $<0.05$ & $<0.01^{w}$ \\
\hline Fasting glucose, mg/dl & $94 \pm 33^{9}$ & $86 \pm 17^{\S}$ & $94 \pm 25$ & $96 \pm 40^{\S}$ & $<0.01^{f}$ & $<0.01^{w}$ \\
\hline LDL cholesterol, mg/dl & $134 \pm 39^{\ddagger}$ & $125 \pm 33$ & $122 \pm 40$ & $119 \pm 36$ & NS & NS \\
\hline Fasting triglycerides, $\mathrm{mg} / \mathrm{dl}^{+}$ & $174 \pm 138$ & $122 \pm 69$ & $142 \pm 115$ & $93 \pm 51$ & $<0.01^{f}$ & $<0.01$ \\
\hline HDL cholesterol, mg/dl & $42 \pm 10$ & $52 \pm 13^{\ddagger}$ & $51 \pm 16$ & $52 \pm 13$ & $<0.01^{\mathrm{m}}$ & $<0.001^{w}$ \\
\hline Total cholesterol/HDL cholesterol & $5.0 \pm 1.4$ & $3.9 \pm 1.1$ & $4.0 \pm 1.4^{\ddagger}$ & $4.2 \pm 1.4$ & $<0.01^{\mathrm{m}}$ & $<0.001^{w}$ \\
\hline Current smoker & $33.0 \%$ & $28.7 \%$ & $54.1 \%$ & $32.1 \%$ & $<0.01^{\mathrm{m}}$ & $<0.01^{b}$ \\
\hline
\end{tabular}

*Analysis of covariance ( $p$ value adjusted for age).

NS indicates $\mathrm{p}>0.05 ;{ }^{\mathrm{f}}$, females only; ${ }^{\mathrm{m}}$, males only; ${ }^{\mathrm{b}}$, blacks only; ${ }^{\mathrm{w}}$, whites only.

${ }^{+}$Mean values are presented and their Log transformed values were used to calculate $p$ values.

${ }^{\ddagger} \mathrm{p}<0.05$ baseline survey vs follow-up survey.

$\S p<0.01$ baseline survey vs follow-up survey.

$" p<0.001$ baseline survey vs follow-up survey.

association between carotid artery IMT and baseline CV risk factors were investigated in a smaller sample of population and relationship with hsCRP was not looked at.

A number of other large, prospective, and populationbased cohort studies have investigated the association between hsCRP and carotid artery IMT progression. The INVADE (intervention project of cerebrovascular events and dementia in the community of Ebersberg) study [11] have found an independent association between baseline hsCRP and common carotid artery IMT progression after 2 years in elderly women but not in men. A considerable number of other epidemiologic studies have found no link between the increased baseline hsCRP levels with carotid artery IMT progression. The Cardiovascular Risk in Young Finns Study reported no association between hsCRP in childhood ( 3 to 18 years of age) with carotid artery IMT 21 years later [17]. The Rotterdam study [10] reported no relation between hsCRP categories and change in common carotid artery IMT during a mean follow-up period of 6.4 years. On the other hand, the same study also reported the relation of hsCRP and the progression of carotid atherosclerosis by the finding of independent and graded associations of hsCRP with the extent and progression of carotid plaques and ankle-brachial index in the elderly men and women $\geq 55$ years of age [10]. Similarly, Carotid Atherosclerosis Progression Study [9] reported that hsCRP was not associated with carotid artery IMT progression after 3 years in middleaged individuals. In our study, we have observed that hsCRP $\geq 2 \mathrm{mg} / \mathrm{l}$ was an independent risk factor for early composite carotid artery IMT progression for the whole study population of young adults.

The role of hsCRP as an acute phase reactant on the progression of early atherosclerosis has not been clarified in detail. High-sensitivity CRP levels might express the inflammatory activity of the atherosclerotic lesion, but 
Table 2 Carotid artery IMT measurements in the baseline and follow-up surveys by race and sex

\begin{tabular}{|c|c|c|c|c|c|c|}
\hline \multirow[b]{2}{*}{ Baseline survey (2001-2002) } & \multicolumn{2}{|c|}{ White } & \multicolumn{2}{|c|}{ Black } & \multicolumn{2}{|c|}{$P$ value* } \\
\hline & $\begin{array}{c}\text { Men } \\
(\mathrm{n}=266) \\
\end{array}$ & $\begin{array}{c}\text { Women } \\
(n=324)\end{array}$ & $\begin{array}{c}\text { Men } \\
(\mathrm{n}=\mathbf{8 5})\end{array}$ & $\begin{array}{c}\text { Women } \\
(n=164)\end{array}$ & Race & Sex \\
\hline Composite CIMT, $\mathrm{mm}^{\dagger}$ & $0.851 \pm 0.175^{\ddagger}$ & $0.760 \pm 0.123^{\S}$ & $0.897 \pm 0.180$ & $0.807 \pm 0.161^{\natural}$ & $<0.01^{f}$ & $<0.001$ \\
\hline Common CIMT, mm ${ }^{\dagger}$ & $0.785 \pm 0.136$ & $0.704 \pm 0.102$ & $0.841 \pm 0.156$ & $0.770 \pm 0.133$ & $<0.01$ & $<0.001$ \\
\hline Bulb CIMT, $\mathrm{mm}^{\dagger}$ & $1.016 \pm 0.311$ & $0.907 \pm 0.213^{\ddagger}$ & $1.051 \pm 0.352$ & $0.943 \pm 0.298$ & $<0.01^{f}$ & $<0.01$ \\
\hline Internal CIMT, mm ${ }^{\dagger}$ & $0.742 \pm 0.211^{\S}$ & $0.674 \pm 0.183^{\S}$ & $0.786 \pm 0.213$ & $0.703 \pm 0.170^{\natural}$ & NS & $<0.01$ \\
\hline \multicolumn{7}{|l|}{ Follow-up survey (2003-2005) } \\
\hline Composite CIMT, $\mathrm{mm}^{\dagger}$ & $0.867 \pm 0.174^{\ddagger}$ & $0.790 \pm 0.162^{\S}$ & $0.892 \pm 0.223$ & $0.836 \pm 0.164^{q}$ & NS & $<0.01^{w}$ \\
\hline Common CIMT, mm ${ }^{\dagger}$ & $0.781 \pm 0.143$ & $0.711 \pm 0.120$ & $0.818 \pm 0.171$ & $0.775 \pm 0.148$ & $<0.01^{f}$ & $<0.001^{w}$ \\
\hline Bulb CIMT, $\mathrm{mm}^{\dagger}$ & $1.032 \pm 0.298$ & $0.942 \pm 0.280^{\ddagger}$ & $1.058 \pm 0.361$ & $0.964 \pm 0.256$ & NS & $<0.05^{w}$ \\
\hline Internal CIMT, mm ${ }^{\dagger}$ & $0.793 \pm 0.232^{\S}$ & $0.711 \pm 0.218^{\S}$ & $0.820 \pm 0.255$ & $0.762 \pm 0.198^{q}$ & NS & $<0.05^{\mathrm{w}}$ \\
\hline
\end{tabular}

*Analysis of covariance ( $p$ value adjusted for age).

NS indicates $p>0.05 ;{ }^{f}$, females only; ${ }^{w}$, whites only.

${ }^{+}$Mean values are presented and their Log transformed values were used to calculate $p$ values.

${ }^{\ddagger} p<0.05$ baseline survey vs follow-up survey.

$\S p<0.01$ baseline survey vs follow-up survey.

$" p<0.001$ baseline survey vs follow-up survey.

hsCRP has been suggested to promote endothelial dysfunction and progression of atherosclerotic lesions in the early stages, and become more pronounced in advanced stages with an important role in plaque vulnerability, rapid progression of plaques, and thrombotic complications [18-20]. Considerable epidemiological evidence has linked increased hsCRP levels with incresed risk of CV events including myocardial infarction, stroke, death from CV causes, coronary revascularization, or a combination of these in middle aged and elderly subjects [9,21-28]. A number of these have suggested this association is independent of traditional CV risk factors [21-27], although others have found it attenuated when risk factors are controlled for $[9,28]$. A number of potential mechanisms by which CRP may play a causal role in atherosclerosis and CV disease have been implicated,

Table 3 Carotid artery IMT progression rates

\begin{tabular}{|c|c|c|c|c|c|}
\hline \multirow[t]{2}{*}{ Site } & \multirow[t]{2}{*}{ Race and sex } & \multirow[t]{2}{*}{$N$} & \multirow{2}{*}{$\begin{array}{c}\text { Mean } \Delta \mathrm{CIMT} \\
\mu \mathrm{m} / \text { year }\end{array}$} & \multicolumn{2}{|c|}{$95 \% \mathrm{Cl}, \mu \mathrm{m} /$ year } \\
\hline & & & & Lower & Upper \\
\hline \multirow[t]{5}{*}{ Composite CIMT* } & All & 695 & 9.2 & 5.3 & 13.0 \\
\hline & White men & 231 & 5.7 & -1.0 & 12.4 \\
\hline & Black men & 70 & 2.8 & -12.0 & 17.5 \\
\hline & White women & 266 & 11.3 & 4.9 & 17.7 \\
\hline & Black women & 128 & 14.5 & 6.5 & 22.3 \\
\hline \multirow[t]{5}{*}{ Common CIMT* } & All & 799 & 0.0 & -3.5 & 3.5 \\
\hline & White men & 256 & -0.8 & -6.2 & 4.7 \\
\hline & Black men & 84 & -9.7 & -24.3 & 4.9 \\
\hline & White women & 302 & 2.6 & -2.5 & 7.6 \\
\hline & Black women & 157 & 1.5 & -7.9 & 11.0 \\
\hline \multirow[t]{5}{*}{ Bulb CIMT* } & All & 768 & 8.8 & 1.4 & 16.1 \\
\hline & White men & 247 & 3.3 & -9.6 & 16.1 \\
\hline & Black men & 79 & 6.2 & -20.1 & 32.5 \\
\hline & White women & 297 & 13.2 & 1.4 & 25.1 \\
\hline & Black women & 145 & 10.3 & -5.3 & 25.8 \\
\hline \multirow[t]{5}{*}{ Internal CIMT* } & All & 706 & 18.9 & 13.0 & 24.9 \\
\hline & White men & 235 & 18.2 & 7.9 & 28.4 \\
\hline & Black men & 71 & 14.7 & -7.8 & 37.2 \\
\hline & White women & 267 & 15.6 & 6.1 & 25.1 \\
\hline & Black women & 133 & 29.2 & 15.9 & 42.5 \\
\hline
\end{tabular}

*Analysis of variance $p>0.05$ among race-sex groups. 


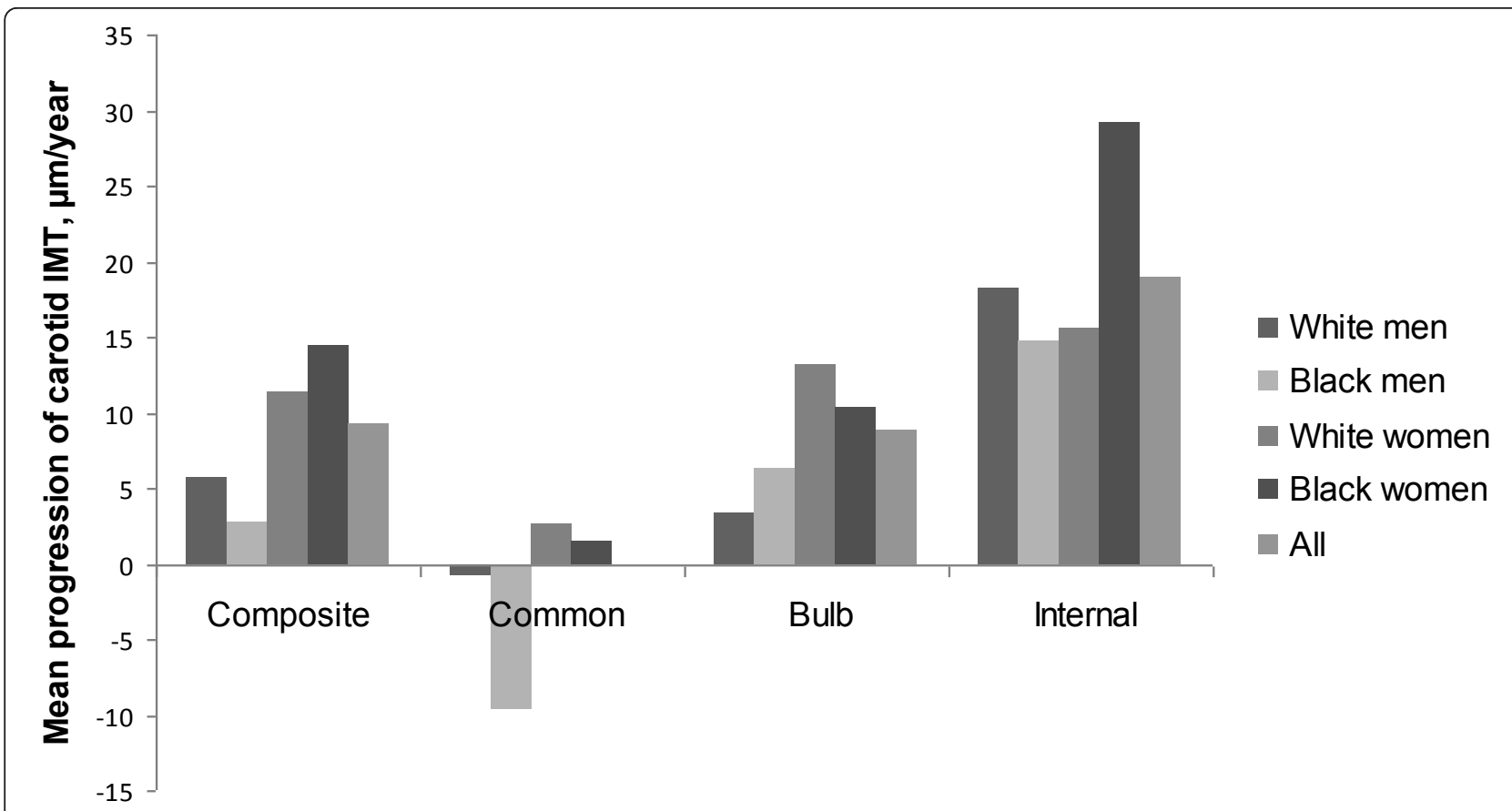

\section{Carotid intima media thickness progression}

Figure 1 Carotid IMT progression rates per year in black and white young adults.

including recruitment of monocytes to the atherosclerotic lesion [29], intimal growth [30], and endothelial dysfunction $[19,31]$.

As might be expected, this study identified baseline predictors of longitudinal carotid artery IMT progression, it is an association study and it is subject to selection bias. CRP is produced in the liver and its concentration is increased by infections that show no relationship to atherosclerosis, as well as by malignancy. Intima-media thickening reflects early atherosclerotic change as well as

Table 4 Baseline independent cardiovascular risk correlates of the composite carotid artery IMT progression in young adults

\begin{tabular}{|c|c|c|c|c|c|c|}
\hline \multirow[b]{2}{*}{ Variables } & \multicolumn{2}{|c|}{$\begin{array}{l}\text { Univariate Associations } \\
\text { (Unadjusted) }\end{array}$} & \multicolumn{4}{|c|}{$\begin{array}{l}\text { Multivariable Model Following Stepwise Selection } \\
\text { (Adjusted for Baseline IMT) }\end{array}$} \\
\hline & $\begin{array}{c}\text { Univariate } \\
\text { Correlations }\end{array}$ & $p$ value & Unstandardized difference* & $95 \% \mathrm{Cl}$ & Standardized difference ${ }^{*}$ & $p$ value \\
\hline Age, years & 0.199 & $<0.001$ & 0.006 & $0.004-0.008$ & 0.208 & $<0.001$ \\
\hline Systolic blood pressure, mm Hg & 0.165 & $<0.001$ & 0.002 & $0.001-0.002$ & 0.171 & $<0.001$ \\
\hline Fasting glucose, mg/dl & 0.129 & $<0.001$ & 0.001 & $0.000-0.001$ & 0.126 & $<0.01$ \\
\hline $\mathrm{hsCRP} \geq 2 \mathrm{mg} / \mathrm{l}$ & 0.110 & $<0.001$ & 0.025 & $0.008-0.043$ & 0.103 & $<0.01$ \\
\hline LDL cholesterol, mg/dl & 0.085 & $<0.01$ & 0.000 & $0.000-0.001$ & 0.088 & $<0.05$ \\
\hline Current smoker & 0.091 & $<0.05$ & 0.021 & $0.003-0.039$ & 0.084 & $<0.05$ \\
\hline Baseline IMT (microns) & $(-0.369)$ & $<0.001$ & $(-0.296)$ & $(-0.353)-(-0.240)$ & $(-0.405)$ & $<0.001$ \\
\hline Gender (women vs men) & 0.035 & 0.37 & 0.008 & $(-0.011)-0.027$ & 0.032 & 0.42 \\
\hline Race (black vs white) & $(-0.025)$ & 0.51 & $(-0.01)$ & $(-0.031)-0.011$ & -0.038 & 0.35 \\
\hline Diastolic blood pressure, mmHg & $(-0.022)$ & 0.57 & 0.000 & $(-0.002)-0.001$ & -0.033 & 0.65 \\
\hline Waist-height ratio & $(-0.002)$ & 0.46 & 0.008 & $(-0.104)-0.121$ & 0.006 & 0.88 \\
\hline HDL cholesterol, mg/dl & 0.021 & 0.6 & 0.000 & $(-0.001)-0.001$ & 0.014 & 0.72 \\
\hline Fasting triglycerides, $\mathrm{mg} / \mathrm{dl}^{+}$ & $(-0.021)$ & 0.59 & $(-0.004)$ & $(-0.022)-0.014$ & $(-0.019)$ & 0.65 \\
\hline
\end{tabular}

Baseline adjusted stepwise linear regression model included age, gender, race, systolic and diastolic blood pressures, waist-height ratio, fasting glucose, serum low density lipoprotein cholesterol, high density lipoprotein cholesterol, fasting triglycerides ${ }^{\dagger}$, high-sensitivity C-reactive protein $\geq 2$ mg/l and smoking status.

*Unstandardized and standardized differences in mean composite carotid artery IMT progression.

${ }^{+}$Log transformed value was used in the model. 
vessel remodeling. The number of subjects with plaques was insufficient to investigate associations with more advanced atherosclerosis in our population. Restricting measurements of IMT to the common carotid artery segment has been justified in other studies by greater reproducibility of measurements from this site and the difficulty in obtaining measurements from the bifurcation or the internal carotid artery in some populations. In the present study, $87 \%$ of all subjects had valid IMT measurements from all segments. Protocols that involve additional segments have several advantages [5]. First, progression is more prominent in the bifurcation and the internal carotid artery. Thus, including these sites may provide the most sensitive and statistically powerful assessment of atherosclerosis progression. Yet, aggregating data across segments may provide measures that are stable and less sensitive to measurement error.

Some methodologic limitations must be taken into account in the interpretation of results. The rate of progression over a 2.4-year period is relatively short and combined with measurement errors, which could be related in part to two different ultrasound machine recordings between surveys, may be responsible for the inability to detect a significant progression of IMT in the common carotid artery segment. Nevertheless, we have identified associations between traditional CV risk factors, hsCRP and composite carotid artery IMT in cross sectional studies in this population. Longer-term follow-up should increase the power to detect other associations and reveal race and gender differences.

\section{Conclusion}

In a prospective, population-based study, we observed independent categorical association of increased hsCRP and multiple conventional risk factors including smoking with carotid artery IMT progression in young adults. This study underlines the importance of assesssing $\mathrm{CV}$ risk factor profiles and hsCRP level in young adults. These observations demonstrate that risk factors are associated with the progression of subclinical atherosclerosis even in young individuals who are at low risk for cardiac events. These observations reflect on the CV risk burden over time by risk factors including inflammation and smoking.

\section{Abbreviations}

hsCRP: high sensitivity c-reactive protein; CV: cardiovascular; IMT: intimamedia thickness; LDL: low-density lipoprotein cholesterol; BMl: body mass index; HDL: high-density lipoprotein cholesterol; INVADE: intervention project of cerebrovascular events and dementia in the community of; Ebersberg; CIMT: carotid artery intima-media thickness.
}

\section{Acknowledgements}

The Bogalusa Heart Study is a joint effort of many investigators and staff whose contributions are gratefully acknowledged. We especially thank
Bogalusa School System, teachers, parents, and most importantly, the participants as children and young adults.

Sources of funding

This work was supported by Grant No. HD-47247 from the National Institute of Child Health and Human Development, Bethesda, Maryland, Grant No. 0555168B from the American Heart Association, Dallas, Texas, Grant No. AG16592 from the National Institute on Aging, Bethesda, Maryland, and Grant No. HL-38844 from the National Heart, Lung, and Blood Institute, Bethesda, Maryland.

\section{Author details}

${ }^{1}$ Tulane University School of Medicine, Heart and Vascular Institute, New Orleans, LA, USA. ${ }^{2}$ Tulane University School of Medicine, Department of Internal Medicine, New Orleans, LA, USA. ${ }^{3}$ Tulane University School of Medicine, Department of Pediatrics, New Orleans, LA, USA. ${ }^{4}$ Tulane Center for Cardiovascular Health, New Orleans, LA, USA.

\section{Authors' contributions}

All authors read and approved the final manuscript. AT: Participated in its design and coordination and drafted the manuscript. RK: Involved in drafting the manuscript and revising it critically for important intellectual content. DT: Involved in drafting the manuscript and revising it critically for important intellectual content. WC: Have made substantial contributions to conception and design, acquisition of data, analysis and interpretation of data, and have given final approval of the version to be published. SS: Have made substantial contributions to conception and design, acquisition of data, analysis and interpretation of data, and have given final approval of the version to be published. JHX Have made substantial contributions to conception and design, acquisition of data, analysis and interpretation of data, and have given final approval of the version to be published. AA: Involved in drafting the manuscript and revising it critically for important intellectual content. GSB: Have made substantial contributions to conception and design, acquisition of data, analysis and interpretation of data, and have given final approval of the version to be published.

\section{Competing interests}

The authors declare that they have no competing interests.

Received: 2 June 2011 Accepted: 30 December 2011

Published: 30 December 2011

\section{References}

1. Stein $\mathrm{JH}$, Korcarz CE, Hurst RT, et al: Use of carotid ultrasound to identify subclinical vascular disease and evaluate cardiovascular disease risk: a consensus statement from the American Society of Echocardiography Carotid Intima-Media Thickness Task Force. Endorsed by the Society for Vascular Medicine. J Am Soc Echocardiogr 2008, 21:93-111, quiz 189-90.

2. Li S, Chen W, Srinivasan SR, et al: Childhood cardiovascular risk factors and carotid vascular changes in adulthood: the Bogalusa Heart Study. JAMA 2003, 290:2271-6.

3. Berenson GS, Srinivasan SR, Bao W, et al: Association between multiple cardiovascular risk factors and atherosclerosis in children and young adults. The Bogalusa Heart Study. N Engl J Med 1998, 338:1650-6.

4. Johnson HM, Douglas PS, Srinivasan SR, et al: Predictors of carotid intimamedia thickness progression in young adults: the Bogalusa Heart Study. Stroke 2007, 38:900-5.

5. Stensland-Bugge $\mathrm{E}$, Bonaa $\mathrm{KH}$, Joakimsen $\mathrm{O}$, Njolstad I: Sex differences in the relationship of risk factors to subclinical carotid atherosclerosis measured 15 years later: the Tromso study. Stroke 2000, 31:574-81.

6. Hashimoto $\mathrm{H}$, Kitagawa $\mathrm{K}$, Hougaku $\mathrm{H}$, et al: C-reactive protein is an independent predictor of the rate of increase in early carotid atherosclerosis. Circulation 2001, 104:63-7.

7. Sander D, Schulze-Horn C, Bickel H, et al: Combined effects of hemoglobin A1c and C-reactive protein on the progression of subclinical carotid atherosclerosis: the INVADE study. Stroke 2006, 37:351-7.

8. Hashimoto $\mathrm{H}$, Kitagawa K, Hougaku $\mathrm{H}$, Etani $\mathrm{H}$, Hori M: C-reactive protein predicts carotid atherosclerosis progression in mild to moderate risk and middle-aged patients. Clin Invest Med 2006, 29:77-82.

9. Lorenz MW, Karbstein P, Markus HS, Sitzer M: High-sensitivity C-reactive protein is not associated with carotid intima-media progression: the carotid atherosclerosis progression study. Stroke 2007, 38:1774-9. 
10. Elias-Smale SE, Kardys I, Oudkerk M, Hofman A, Witteman JC: C-reactive protein is related to extent and progression of coronary and extracoronary atherosclerosis; results from the Rotterdam study. Atherosclerosis 2007, 195:e195-202.

11. Sander K, Horn CS, Briesenick C, Sander D: High-sensitivity C-reactive protein is independently associated with early carotid artery progression in women but not in men: the INVADE Study. Stroke 2007, 38:2881-6.

12. Hodis HN, St John JA, Xiang M, et al: Inflammatory markers and progression of subclinical atherosclerosis in healthy postmenopausal women (from the Estrogen in the Prevention of Atherosclerosis Trial). Am J Cardiol 2008, 101:1131-3.

13. The Bogalusa Heart Study 20th Anniversary Symposium. Am J Med Sci 1995, 310:S1-S138.

14. Berenson GS, McMahan CA, Voors AV, et al: Cardiovascular Risk Factors in Children-The Early Natural History of Atherosclerosis and Essential Hypertension.Edited by: Andrews C, Hester HE. New York: Oxford University Press; 1980:47-123

15. High-resolution B-mode ultrasound reading methods in the Atherosclerosis Risk in Communities (ARIC) cohort. The ARIC Study Group. J Neuroimaging 1991, 1:168-72.

16. Tang R, Hennig M, Thomasson B, et al: Baseline reproducibility of B-mode ultrasonic measurement of carotid artery intima-media thickness: the European Lacidipine Study on Atherosclerosis (ELSA). J Hypertens 2000, 18:197-201.

17. Juonala M, Viikari JS, Ronnemaa T, et al: Childhood C-reactive protein in predicting CRP and carotid intima-media thickness in adulthood: the Cardiovascular Risk in Young Finns Study. Arterioscler Thromb Vasc Biol 2006, 26:1883-8.

18. Willeit J, Kiechl S: Biology of arterial atheroma. Cerebrovasc Dis 2000, 10(Suppl 5):1-8.

19. Pasceri $\mathrm{V}$, Willerson JT, Yeh ET: Direct proinflammatory effect of C-reactive protein on human endothelial cells. Circulation 2000, 102:2165-8.

20. Fuster V, Moreno PR, Fayad ZA, Corti R, Badimon JJ: Atherothrombosis and high-risk plaque: part I: evolving concepts. J Am Coll Cardiol 2005, 46:937-54.

21. Ridker PM, Hennekens $\mathrm{CH}$, Buring JE, Rifai N: C-reactive protein and other markers of inflammation in the prediction of cardiovascular disease in women. N Engl J Med 2000, 342:836-43.

22. Blake GJ, Rifai N, Buring JE, Ridker PM: Blood pressure, C-reactive protein, and risk of future cardiovascular events. Circulation 2003, 108:2993-9.

23. Cao JJ, Thach C, Manolio TA, et al: C-reactive protein, carotid intimamedia thickness, and incidence of ischemic stroke in the elderly: the Cardiovascular Health Study. Circulation 2003, 108:166-70.

24. Curb JD, Abbott RD, Rodriguez BL, et al: C-reactive protein and the future risk of thromboembolic stroke in healthy men. Circulation 2003, 107:2016-20

25. Koenig W, Lowel H, Baumert J, Meisinger C: C-reactive protein modulates risk prediction based on the Framingham Score: implications for future risk assessment: results from a large cohort study in southern Germany. Circulation 2004, 109:1349-53.

26. Danesh J, Wheeler JG, Hirschfield GM, et al: C-reactive protein and other circulating markers of inflammation in the prediction of coronary heart disease. N Engl J Med 2004, 350:1387-97.

27. Tanne D, Benderly M, Goldbourt U, et al: C-reactive protein as a predictor of incident ischemic stroke among patients with preexisting cardiovascular disease. Stroke 2006, 37:1720-24.

28. Bots MJ, Schipper CM, Koudstaal PJ, et al: High serum C-reactive protein level is not an independent predictor for stroke: the Rotterdam Study. Circulation 2006, 114:1591-98.

29. Torzewski M, Rist C, Mortensen RF, et al: C-reactive protein in the arterial intima: role of $\mathrm{C}$-reactive protein receptor-dependent monocyte recruitment in atherogenesis. Arterioscler Thromb Vasc Biol 2000, 20:2094-9.

30. Wang $\mathrm{CH}$, Li SH, Weisel RD, et al: C-reactive protein upregulates angiotensin type 1 receptors in vascular smooth muscle. Circulation 2003, 107:1783-90.

31. Li L, Roumeliotis N, Sawamura T, Renier G: C-reactive protein enhances LOX-1 expression in human aortic endothelial cells: relevance of LOX-1 to C-reactive protein-induced endothelial dysfunction. Circ Res 2004 95:877-83

\section{Pre-publication history}

The pre-publication history for this paper can be accessed here: http://www.biomedcentral.com/1471-2261/11/78/prepub

doi:10.1186/1471-2261-11-78

Cite this article as: Toprak et al:: C-reactive protein is an independent predictor for carotid artery intima-media thickness progression in asymptomatic younger adults (from the Bogalusa Heart Study). BMC Cardiovascular Disorders 2011 11:78.

\section{Submit your next manuscript to BioMed Central and take full advantage of:}

- Convenient online submission

- Thorough peer review

- No space constraints or color figure charges

- Immediate publication on acceptance

- Inclusion in PubMed, CAS, Scopus and Google Scholar

- Research which is freely available for redistribution

Submit your manuscript at www.biomedcentral.com/submit
C) Biomed Central 